Jurnal Bisnis dan Manajemen, Volume 21, No. 2, September 2020, p. 129-143

\title{
EFFECT OF TOURIST CHARACTERISTICS AND RESOURCES ON IMAGE: STUDY OF CILETUH GEODIVERSITY AREA SUKABUMI
}

\author{
Ernie Tisnawati Sule ${ }^{1}$ \\ Universitas Padjadjaran, Indonesia
}

\begin{abstract}
Ciletuh Geopark, located in Sukabumi regency, is one of the promising tourist destinations in West Java. This research aims to explore the effect of tourist characteristics and resources on the image of Ciletuh Geopark. This research is quantitative, employing a time horizon of cross-sectional. The analysis unit of this research is visitors at the geodiversity area of Ciletuh, while the observation unit is the visitors or tourists visiting this area at the end of 2019. The sample of this study is 100 visitors. The partial least square (PLS) is used for analyzing the causal relationship between variables. The research results show that tourist characteristics and resources affect the image. Resources have a more substantial effect than the tourist characteristics do. This study implies that the management of Ciletuh Geopark needs to pay more attention to developing and managing the resources, primarily the natural resources, cultural resources, and human resources. Besides, this effort needs to be supported by the understanding of tourist characteristics. Hence, the image of the destination will be enhanced.
\end{abstract}

Keywords: tourist characteristics, resources, image, geopark.

\section{PENGARUH KARAKTERISTIK WISATAWAN DAN SUMBER DAYA TERHADAP IMAGE: PENELITIAN PADA AREA GEODIVERSITAS CILETUH SUKABUMI}

\begin{abstract}
ABSTRAK
Geopark Ciletuh merupakan salah satu destinasi wisata potensial di Kabupaten Sukabumi, Jawa Barat. Penelitian ini bertujuan untuk menguji pengaruh tourist characteristic and resources terhadap image Geopark Ciletuh. Penelitian ini merupakan penelitian kuantitatif. Penelitian dilakukan pada time horizon yang bersifat cross sectional, karena dilakukan pada waktu tertentu. Unit analisis dari penelitian ini adalah pengunjung pada Kawasan Geodiversity Ciletuh. Sedangkan unit pengamatannya adalah pengunjung Geopark tersebut pada akhir tahun 2019 dengan sampel sebanyak 100 pengunjung. Analisis kausalitas digunakan untuk mengetahui hubungan sebab akibat di antara variabel. Analisis ini menggunakan PLS. Hasil penelitian ini menunjukkan bahwa tourist characteristic and resources berpengaruh pada image. Resources memiliki pengaruh yang lebih besar dibandingkan tourist characteristic dalam meningkatkan image. Hasil penelitian ini memberikan implikasi bagi manajemen pengelola wisata Geopark Ciletuh dalam rangka meningkatkan image destinasi tersebut, dengan mengupayakan pengembangan dan pengelolaan resources terutama aspek natural resources, cultural resources, dan human resources yang dimiliki. Upaya tersebut, juga perlu ditunjang dengan pemahaman mengenai aspek-aspek tourist characteristic yang akan mampu meningkatkan image destinasi tersebut.
\end{abstract}

Kata-kata kunci: karakteristik wisatawan, sumber daya, image, geopark.

\footnotetext{
${ }^{1}$ Korespondensi: Prof. Dr. Ernie Tisnawati Sule, S.E., M.S. Fakultas Ekonomi dan Bisnis, Universitas Padjadjaran. Jln. Dipati Ukur No. 35 Kota Bandung. Email: ernie.tisnawati.fe@unpad.ac.id
}

Submitted: June 2020, Accepted: September 2020, Published: September 2020

ISSN: 1412 - 3681 (printed), ISSN: 2442 - 4617 (online), Website: http://journal.feb.unpad.ac.id/index.php/jbm 
Jurnal Bisnis dan Manajemen, Volume 21, No. 2, September 2020, p. 129-143

\section{INTRODUCTION}

Ciletuh Geopark is one of the potential tourist destinations in West Java province. It is located in Sukabumi Regency, and it is also called the hidden paradise of Sukabumi. In 2015, UNESCO recognized the splendidness of this area. Ciletuh Geopark has several fabulous tourist spots, namely Pantai Ujung Genteng, Bukit Teletubbies, Pantai Cimaja, Curug Puncak Manik, Pantai Palangpang, Puncak Darma, Puncak Tugu, Bukit Panenjoan, Bukit Gebang, and Air Terjun Cimarinjung.

Ciletuh Geopark offers the management concept for a tourist destination by harmonizing the diversity of geology, nature, culture through conservation, education, and sustainable development. Ciletuh Geopark, with an area of 128 thousand hectares, includes eight subdistricts in Sukabumi regency. Ciletuh Geopark is famous for its biodiversity, culture, as well as natural landscape.

According to UNESCO, geopark is an area that has outstanding geological elements including archeological, ecological, and cultural values - in which local people are invited to participate in protecting and enhancing the function of natural heritage. The elements of geopark consist of three, namely, geodiversity, biodiversity, and cultural diversity. In early 2020, Ciletuh Palabuhanratu UNESCO Global Geopark (CPUGGp) was started to be developed to attract more visitors, and the three elements of geopark had been fulfilled. The formulations to a world- class tourist destination should consist of attraction, access, and tourism resource (Adiakurnia, 2018).

According to Ciletuh Geopark Information Center (GIC), the number of visitors to Ciletuh Geopark in January-November 2017 reached 967,311 visitors, consisting of 802,868 local tourists and 164,443 foreign visitors. When it first opened in 2012, the number of visitors to Ciletuh was 343,910 visitors. In 2017, among eight subdistricts in Ciletuh-Palabuhanratu Geopark, the Palabuhanratu subdistrict had the most visitors of 416,323 visitors, followed by Ciracap, Surade, and Cisolok with visitors of $281,670,168,100$, and 56,260 visitors, respectively (Soedarsono, 2018).

The foreign visitors of Ciletuh Geopark were mostly from France (26.3\%) and Australia (21.1\%), followed by tourists from Germany, the United States of America, Singapore, and South Africa. Most of the tourists came to Ciletuh Geopark for vacation, surfing, and beaching. Around $63.2 \%$ of surfers acknowledged that the waves in Cieltuh, primarily in, Palabuhanratu Bay are appropriate for water sport such as surfing. Most of the visitors stayed in Ciletuh for around four to seven days, with most of them preferred homestay (52.6\%) instead of staying in hotels. The local visitors mostly came from the West Java area, primarily from the Sukabumi area, and they are mostly students and college students. They also had the same reason as foreign tourists, namely, vacation $(77.2 \%)$, and the rest came for 
Jurnal Bisnis dan Manajemen, Volume 21, No. 2, September 2020, p. 129-143

study purposes. Most of the local visitors obtained information about Ciletuh-Palabuhanratu Geopark from social media (47.88\%), and the rest obtained it from friends and family members. In contrast, most foreign visitors obtained information from a website or blog (47.4\%) and social media (15.8\%) (Soedarsono, 2018).

The image plays an essential role in increasing the visit to a tourist destination. Hence, every tourist destination should increase its image so the number of visitors can increase. Besides, people's income, job opportunities, and government income can increase, as well. Therefore, image is considered crucial by visitors before deciding to visit a destination (Cai, Wu, \& Bai, 2004). Image of a tourist destination is defined as the representation of the individual mentality resulted from knowledge, feeling, and the whole perception of a particular purpose (Fakeye \& Crompton, 1991).

An image of a destination is an essential factor in tourists' perceptions and assessments (Huete-Alcocer, et al. 2019). However, the creation of the destination image is affected by numerous factors that are often overlooked by many researchers (Kim, et al. 2017). Madden, Rashid, \& Zainol (2016), as cited by Beerli \& Martin (2004), state that the image of any destination comprises the observations about "natural and cultural resources, general, tourist and leisure infrastructures, atmosphere, social setting and environment, sun \& sand, knowledge, relaxation, entertainment, and prestige." From these statements, it is clear that resources are the antecedent of any tourist destination image.

As a tourist destination, Ciletuh Geopark has tremendous natural and cultural resources. Several cultural attractions are also available, such as Helaran Budaya Pajampangan, Rampak Lodong, Paragliding attractions, Rock Climbing attractions, Beach Railing attractions, and planting of Kepuh trees. Besides, it is also essential to develop a tourist destination by supporting its human resources.

However, there have been complaints submitted by tourists regarding the high price of food and the existence of illegal levies by unscrupulous residents. Also, there are complaints about waste management in tourist areas, where there is still much garbage scattered when many tourists are coming. The mindset of residents still needs to be improved to become major players in the development of these tourist areas. Currently, people are still afraid to be just spectators. There are still many people who have not thought about taking part in tourism activities in that place. Some of them have participated by making various handicrafts typical of Sukabumi or Geopark Ciletuh as souvenirs for tourists. Besides that, this tourist area also still needs improvement in terms of infrastructure.

Based on the research results of Putri, Deliarnoor \& Nurasa (2020) regarding the Implementation of West Java Provincial Government Policies Regarding Geopark Area 
Jurnal Bisnis dan Manajemen, Volume 21, No. 2, September 2020, p. 129-143

Development, several problems are identified, namely:

1. Geopark management with a conservation function has not been achieved because the government and the community are only limited to waste management and tree planting efforts.

2. In terms of human resources, their quantity is sufficient as there is Ciletuh Geopark Development Coordination Team. However, in quality, especially from the community, many do not care and lack understanding of the surrounding community, especially in nature conservation efforts.

3. Regarding financial resources, although it can be said that there is a budget that has been allocated for Ciletuh Development, this budget is still insufficient and requires assistance from the center.

4. Regarding infrastructure resources, in the development of the Ciletuh Geopark, construction has been carried out such as the main access road to the Ciletuh Geopark Area such as the Trans Loji Road from the Ciletuh Geopark to the core point of Ciemas Subdistrict, the Construction of the Cibenda Geosite Area Track, Construction of Roads from the Gate to the View Deck Area Feosite Cibenda Welcome Gate Development, Road Markings Construction, Street Lighting Development, lodging facilities as well as toilet facilities and health facilities. However, the availability of infrastructure is still inadequate. For example, the number of lights and road markings is still minimal, and road access to several tourist objects is still difficult and has not been repaired.

5. In terms of time resources, referring to the 2017-2025 Ciletuh Geopark Development Master Plan, the target time for Ciletuh development is eight years. However, in the Ciletuh Geopark Development Policy to the Ciletuh Geopark being globally competitive tourism, no time limit has been set.

6. In terms of communication between organizations and implementing activities, it is evident that coordination is still not optimal among implementing agencies for the Ciletuh Development Policy.

Thus, it is essential to study the effect of resources on the image of Ciletuh Geopark as a dependable tourist destination in West Java province, Indonesia.

Data from the Geopark Information Center (GIC) in 2019 shows that the number of visitors to Ciletuh Geopark continues to increase every year. In 2014 , there were 343,910 visits by tourists and increased to $1,041,053$ tourists in 2018. The research results of Triana, Nuraini \& Rusfien (2019) revealed that Ciletuh Geopark visitors were dominated by women. The majority of 
Jurnal Bisnis dan Manajemen, Volume 21, No. 2, September 2020, p. 129-143

visitors are aged 17-39 years. Most of the visitors work in the entrepreneurial field.

Beerli \& Martín (2004) studied the formation of the image of tourist destinations through empirical research utilizing a representative sample consisting of visitors to Lanzarote Island (Canary Islands, Spain). They found that the internal characteristics or the personal factors of visitors affect the components of the tourist destination's image. Besides, Aksoy \& Kiyci (2011) studied the fundamental variables affecting the formation of the image. They found that demographic information such as income and education influence the image of a tourist destination. Tourist characteristics play a role in affecting visit intention among the visitors. Based on this, it is interesting to study the influence of tourist characteristics on the Ciletuh Geopark image.

Based on the explanations above, this study aims to examine the effect of tourist characteristics and resources on the image of Ciletuh Geopark.

\section{LITERATURE REVIEW}

Tourists are those who involve in tourism activities (Newsome, Moore \& Dowling, 2012, p. 9). Several studies have researched tourism. Hosany, Ekinci \& Uysal (2007) studied the sociodemographic characteristics of tourists, consisting of gender, age, annual personal income, number of previous visits, the purpose of visit, and travel companion. Meanwhile, Beerli \&
Martín (2004) studied the formation process of the tourist destination image. They studied the tourists visiting Lanzarote Island in Spain and found that the internal characteristics or personal factors of the tourists affect several components of the destination image.

Gaffar, Wetprasit \& Setiyorini (2011, p.55) stated that the characteristics of tourists are often used as a reference for analyzing market segmentation and marketing efforts to implement the strategy. The characteristics of tourist influence the decision to make a visit to a destination. These characteristics include demographic characteristics, time and duration of visit, expenditure, the purpose of visit, type of transportation used, and type of accommodation used. Some characteristics of tourists that can be analyzed are gender, age, educational level, occupation, and income. Gaffar et al. (2011) analyzed the tourist characteristic based on gender, age, educational level, occupation, and income. Luo, Feng \& Cai (2004) investigated demographic characteristics of tourist including age, gender, household income, education, dan occupation. While Ma, Chow, Cheung, Lee, \& Liu (2018) investigated sociodemographic and visitation characteristics include gender, age, occupation, education, and monthly income in China's tourism context. Thus, in this present study, the tourist characteristics are measured by demographics and attributes.

The destination is a physical space that includes tourism products, such as support 
Jurnal Bisnis dan Manajemen, Volume 21, No. 2, September 2020, p. 129-143

services and attractions, and tourism resources. Every destination has physical and administrative boundaries that define its management, images, and perceptions that in turn, define its market competitiveness. Destinations also integrate many stakeholders, as well as a host community (World Tourism Organization, 2003).

A destination comprises six components that called the six $A(s)$, including attractions (natural, man-made, artificial, purpose built, heritage, special events); accessibility (transportation comprised of routes, terminals and vehicles); amenities (accommodation, catering facilities, retailing, other tourist services); available packages (pre-arranged packages by intermediaries and principals); activities (what consumers do during their visit at the destination); and ancillary services (services used by tourists such as banks, telecommunication, post, newsagents, and hospitals) (Buhalis, 2000). Some of these components are included in tourism resources.

The significance of the resources of a tourist destination has been studied by Vengesayi, Mavondo \& Reisinger (2013), investigating the determinants of tourism destination competitiveness in a developing country. They examined the influence of destination resources, support services, and human resources on the competitiveness of Zimbabwe as a tourism destination. The findings revealed that the destination support services and human resources related factors were found to be the primary determinants of destination competitiveness. Destination resources were the secondary determinants.

The hospitality of people, culture, and natural resources are essential for any country in developing the tourism sector (World Economic Forum, 2013). The countries which can offer tourists access to nature will have a competitive advantage. Besides, the quality of human resources will ensure that that industry has access to the required partners, so the tourism sector will grow and develop (World Economic Forum, 2013). Besides, cultural resource is another critical driver of competitiveness for any country. The image of a tourist destination is affected by numerous factors, often missed in single research (Kim, et al. 2017).

Destination resources are destination strategic assets that determine the level of activity a destination can achieve. The availability of resources within a destination is essential for its performance; destination resources enhance its competitiveness by attracting entrepreneurs who invest in facilities and thus enable the destination to attract tourists (Melian-Gonzalez \& GarciaFalcon, 2003).

Hadinoto (1996) in Yusuf, Rostitawati \& Obie $(2019$, p. 5), revealed five types of components support or determine the development of a tourist attraction, namely (a) tourist attractions. The identified attractions, such as natural resources, human resources, culture, etcetera, need to be developed to become tourist 
Jurnal Bisnis dan Manajemen, Volume 21, No. 2, September 2020, p. 129-143

attractions; (b) Promotion and marketing; (c) Tourist market; (d) Transportation, and (e) Tourist recipient communities. It shows the importance of resources of a tourism destination. They found some cultural and natural resources problems as a tourism destination in Gorontalo specific destinations, namely, poor hygiene, minimal infrastructure, and inadequate educational conditions of residents around tourism destinations, thus affecting the service quality. Besides, the information on tourism destination objects to the public still lacks and ineffective. Road access and human resources managing tourist objects are inadequate.

Itamar, Alam \& Rahmatullah (2014) found problems that often hinder tourism development: road access and facilities. Not all tourist attractions are located on the side of the highway. Besides, axle roads, damaged roads, and potholes are factors inhibiting tourism development; inadequate human resource management; 3) weak regulations and legal basis; 4) Management of overlaps between the government, foundations or families, and the private sector.

Based on those works of literature, this present study utilizes three dimensions of resource variable, namely, natural resources, human resources, and cultural resources.

For any tourist destination, it is possible to define an image as the pieces of evidence, for instance, shape, slogan, picture, writing, and any pretty amenities, which make an impression in target people's minds. Thus, image is a portrayal that appeals to visitors to a region and causes them to use money there (Şahbaz, 2008, p. 2, in Aksoy \& Kiyci, 2011, p.479). Madden, Rashid, Zainol (2016), citing Beerli \& Martin (2004), stated that any tourist destination image includes natural and cultural resources, infrastructures, atmosphere, social setting and environment, sun \& sand, knowledge, relaxation, entertainment, and prestige. Madden, Rashid \& Zainol (2016) also explained that a favored tourist destination results from the mix between many attributes, such as landscape, shopping centers, cultural performances, facilities, and safety aspects.

The image that prospective tourists own about a destination is the primary determinant of the future visit. An image has been a factor which is essential because the tourism product itself is intangible and alike. Therefore, the primary purpose of a positioning strategy is to make a constructive image of the destination and reinforce it (Özdemir, 2007:105, in Aksoy \& Kiyci, 2011, p.481).

Image may bring tourists to the past experiences they have ever had (Fakeye \& Crompton, 1991). Phelps (1986) defined the primary image as the image constructed after visiting a destination. The image can also contain persuasive information (Fakeye \& Crompton, 1991), and the organic image can from noncommercial (independent) sources. Also, the formal or induce image comes from the commercial organization responsible for managing a destination. 
Jurnal Bisnis dan Manajemen, Volume 21, No. 2, September 2020, p. 129-143

Lopes (2011) analyzed the latest guidelines for Tourism Marketing that the development of the image of a tourist destination is based on the consumer's rationality and emotionality. Besides, it is the result of the combination of two main components or dimensions. First is perceptual and cognitive, meaning there is a primacy of the importance and value given to each tourist destination attribute, motivating tourists to visit that destination. The second is affective. It refers to feelings and emotions raised by tourist destinations. $\mathrm{He}$ suggested that the destination image is one of the most critical elements of a tourist destination and becomes a critical factor for the success or failure of tourism management. Lopes (2011) described the type of information used depending on the image as shown in Figure 1 (Adapted from Fakeye \& Crompton, 1991).
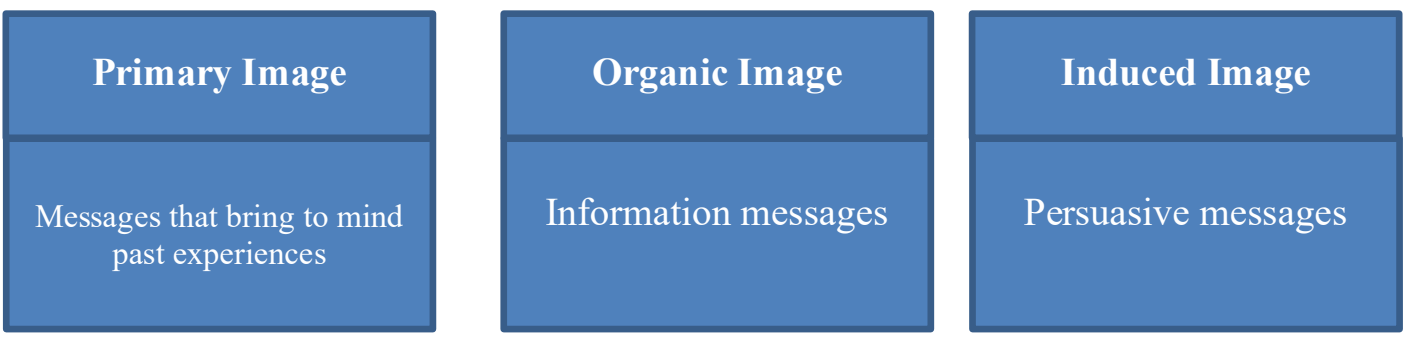

\section{Figure 1. Type Of Information Used Depending On The Type Of Image (Adapted from Fakeye \& Crompton, 1991)}

Source: Lopes (2013, p.311)

Phelps (1986) in Lopes (2011) defined the primary image as the image built after visiting the destination. Organic image is all of the information transmitted unintentionally by representatives of tourism destinations. Such information may be transmitted either via television, radio, books on geography or history, newspapers, magazines, or by people living at a tourist destination. Induced image is the image formed by the promotions and communications of the tourism organizations involved in a region (Gunn, 1972 in Lopes, 2011, p.310).
Based on those previous studies, this present study utilizes an image with the following dimensions, namely, primary image, organic image, and induce image.

Several previous studies have tested the relationship between tourist characteristics and resources with the image of the destination. Lopes (2011) shows that variables such as age, race, the fact that a person has visited a destination before, their level of education, motivation, and cultural values strongly influence the image of a destination that is created. It shows the 
Jurnal Bisnis dan Manajemen, Volume 21, No. 2, September 2020, p. 129-143

relationship between the tourist characteristic and the destination image.

Jamaludin, Aziz, Yusof \& Idris (2013) examined the relationship between information sources and destination image and the relationship between destination image and overall satisfaction among local visitors. The finding revealed the existence of causal relationships between information sources and destination image, leading to positive visitors' satisfaction. "The image of a destination is a key element to attract tourists. The landscape and the variety of resources make a destination particularly attractive for the different types of tourists" (Abdellatif, Ksouri, Ayoun \& Storai, 2015).

Therefore, based on the finding of previous literature, which show the relationship between tourist characteristics and resources with the image, then the hypothesis of this study is as follows:

Ha: tourist characteristics and resources affect the image.

\section{METHODS}

This present study is a quantitative study using a time horizon of cross-sectional. The analysis unit in this study is visitors at Ciletuh Geopark in Sukabumi, West Java. The observation unit of this study is tourists visiting that area at the end of 2019. This study's sample was 100 people who were taken from visitors who were at the research site (Ciletuh Geopark) by accidental sampling.
Questionnaires were distributed by visiting these visitors.

The questionnaire consisted of two questions; closed and open questions. The questionnaire primarily uses closed questions about the research variables. Besides, open questions about questions outside the research variables were presented, allowing the researcher to dig more in-depth information. At the beginning of the questionnaire, it was asked about identity, namely age, sex, year of birth, and other variables that were useful for analysis.

The causality analysis is employed to explore the causal relationship between the variables. In this study, Partial Least Square (PLS) is used consisting of two linear equations, namely, the inner model and outer model. The structural model represents the relationship between latent variables, which cannot be measured directly. The measurement model of this study considers the relationship between latent variables and a group of manifest variables, which can be measured directly.

\section{RESULTS AND DISCUSSION}

\section{Goodness of Fit}

The Goodness of fit is a statistical evaluation of the overall model to be used. It acts as a guideline to assess the model appropriateness between the theoretical-based research model and empiricalbased data. Structural Equation Model (SEM) is not one of the best statistical tests to explain the predictive power of a model, and there are several 
Jurnal Bisnis dan Manajemen, Volume 21, No. 2, September 2020, p. 129-143

index criteria to assess the suitability of the model. describes the actual conditions. The following is Furthermore, the Goodness of fit model has the the Goodness of fit results of this study. objective to test whether the resulting model

Table 1. Goodness of Fit

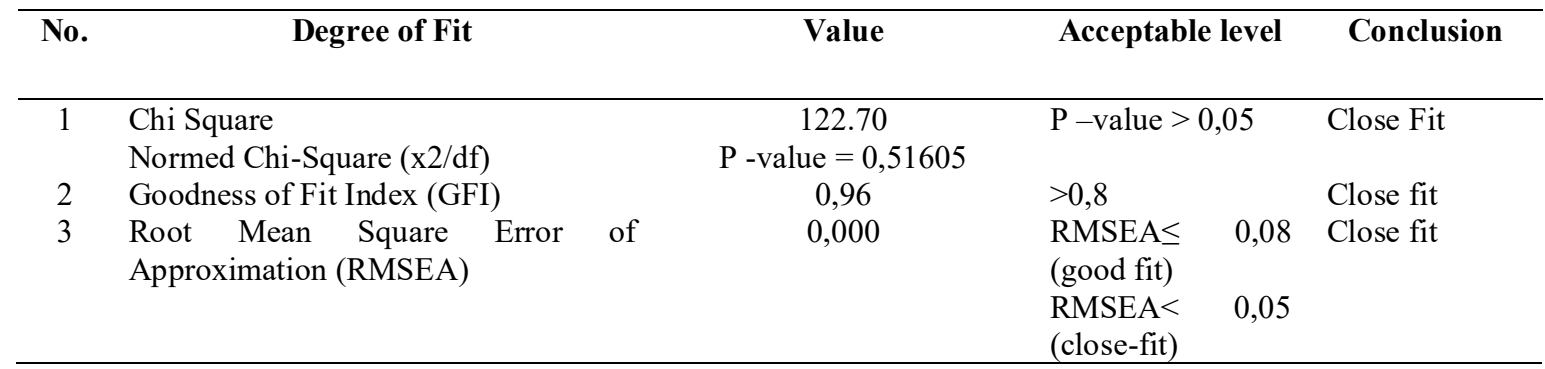

Source: Processed data (2019)

Based on Table 1, the value of Chi-Square uses the value of Satorra-Bentler (Satorra-Benteler Scaled). As shown in Table 1, the Chi-Square value, with the Degree of Freedom of 124, is 122.70, and the p-value of Chi-Square $>0.05$. Thus, according to the Chi-Square index, the suitability of this research model is fitted (Hair et al., 2010).

The RMSEA of this research model is 0.00. RMSEA is smaller than 0.05. Besides, the
Goodness of Fit Indice $(\mathrm{GFI})>0.80$. So, it can be concluded that the research model is under empirical conditions. Hence, the structural model framework in this study is as follows:

$$
\text { Image }=0.19 C H A R+0.53 R \text { esources }+\zeta_{1}
$$

The following Figure 2 is the complete path diagram model of the research model. 


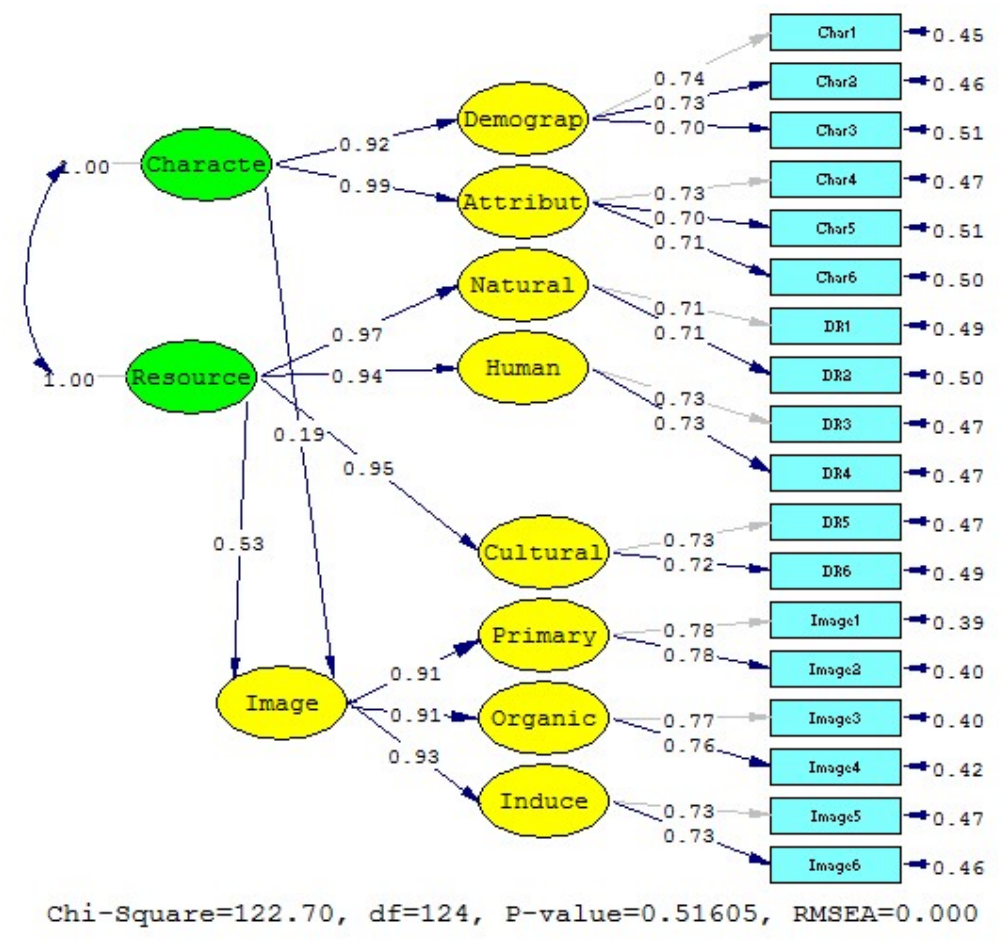

Figure 2. Structural Models and Measurements

The loading factor of the measurement model is higher than 0.50 , or the $\mathrm{t}$-calculated value of the loading factor is higher than the ttable at 5\% significance (Chin, 2000). So, the dimensions are valid in measuring the variables. The Composite Reliability and Cronbach's Alpha are used to see the reliability level of the dimensions in measuring research variables. If the Cronbachs Alpha value is larger than 0.70 (Nunnally, 1994), the dimensions and indicators are reliable in measuring the research variables. The values of Cronbachs Alpha and other data are shown in Table 2.

Table 2. Dimension-Indicator Measurement Model

\begin{tabular}{clccccc}
\hline Variable & $\begin{array}{c}\text { Dimension } \\
\text { and Indicator }\end{array}$ & $\boldsymbol{\lambda}$ & $\begin{array}{c}\text { Standard } \\
\text { Error }\end{array}$ & $\begin{array}{c}\text { t- } \\
\text { calculated } \\
\text { value }\end{array}$ & $\begin{array}{c}\text { Composite } \\
\text { Reliability }\end{array}$ & $\begin{array}{c}\text { Cronbach's } \\
\text { Alpha }\end{array}$ \\
\hline $\begin{array}{c}\text { Tourist } \\
\text { Characteristics }\end{array}$ & Demographic & 0,92 & 0,15 & 8,44 & 0,91 & 0,78 \\
& Char1 & 0,74 & 0,45 & - & & \\
& Char2 & 0,73 & 0,47 & 11,43 & & \\
& Char3 & 0,70 & 0,51 & 11,01 & & \\
& Attribute & 0,99 & 0,02 & 8,54 & & \\
& Char4 & 0,73 & 0,47 & - & & \\
Resources & Char5 & 0,70 & 0,51 & 10,71 & & \\
& Char6 & 0,71 & 0,50 & 10,83 & & \\
& Natural & 0,97 & 0,02 & 12,24 & 0,93 & \\
& DR1 & 0,71 & 0,50 & - & & \\
& DR2 & 0,71 & 0,50 & 10,51 & & \\
& Human & 0,94 & 0,12 & 12,16 & & \\
\hline
\end{tabular}

Submitted: June 2020, Accepted: September 2020, Published: September 2020

ISSN: 1412 - 3681 (printed), ISSN: 2442 - 4617 (online), Website: http://journal.feb.unpad.ac.id/index.php/jbm 
Jurnal Bisnis dan Manajemen, Volume 21, No. 2, September 2020, p. 129-143

\begin{tabular}{|c|c|c|c|c|c|c|}
\hline \multirow{14}{*}{ Image } & DR3 & 0,73 & 0,47 & - & \multirow{14}{*}{0,93} & \multirow{14}{*}{0,74} \\
\hline & DR4 & 0,73 & 0,47 & 10,81 & & \\
\hline & Cultural & 0,95 & 0,10 & 12,22 & & \\
\hline & DR5 & 0,73 & 0,47 & - & & \\
\hline & DR6 & 0,72 & 0,48 & 10,66 & & \\
\hline & Primary & 0,91 & 0,17 & 11,81 & & \\
\hline & Image 1 & 0,78 & 0,39 & - & & \\
\hline & Image2 & 0,78 & 0,39 & 12,15 & & \\
\hline & Organic & 0,91 & 0,17 & 11,76 & & \\
\hline & Image3 & 0,77 & 0,41 & - & & \\
\hline & Image4 & 0,76 & 0,42 & 11,87 & & \\
\hline & Induce & 0,93 & 0,14 & 11,28 & & \\
\hline & Image 5 & 0,73 & 0,47 & - & & \\
\hline & Image6 & 0,73 & 0,47 & 10,86 & & \\
\hline
\end{tabular}

\section{Hypothesis Testing}

Table 3 shows the results of the hypothesis testing of this study.

*sig. at $\alpha=0.05$

Table 3 shows that the effect of Tourist

Table 3. Partial Testing

\begin{tabular}{lcccc}
\hline Hypothesis & $\gamma$ & $\mathbf{S E}(\gamma)$ & $\begin{array}{c}\mathbf{t}- \\
\text { calculated } \\
\text { value }\end{array}$ & $\mathbf{R}^{2}$ \\
\hline $\begin{array}{l}\text { Tourist } \\
\begin{array}{l}\text { Charachteristi } \\
\text { c - Image }\end{array}\end{array}$ & 0,19 & 0,064 & $2,91^{*}$ & 0,06 \\
$\begin{array}{l}\text { Resources -> } \\
\text { Image }\end{array}$ & 0,53 & 0,076 & $7,01^{*}$ & 0,30 \\
\hline
\end{tabular}

Characteristics and Resources on Image is significant because the $t$-calculated value is larger than the t-table (1.96). Besides, it is shown that the variable of Resources influences image by $30 \%$.

Based on the hypothesis testing, the model of this research can be shown as follows:

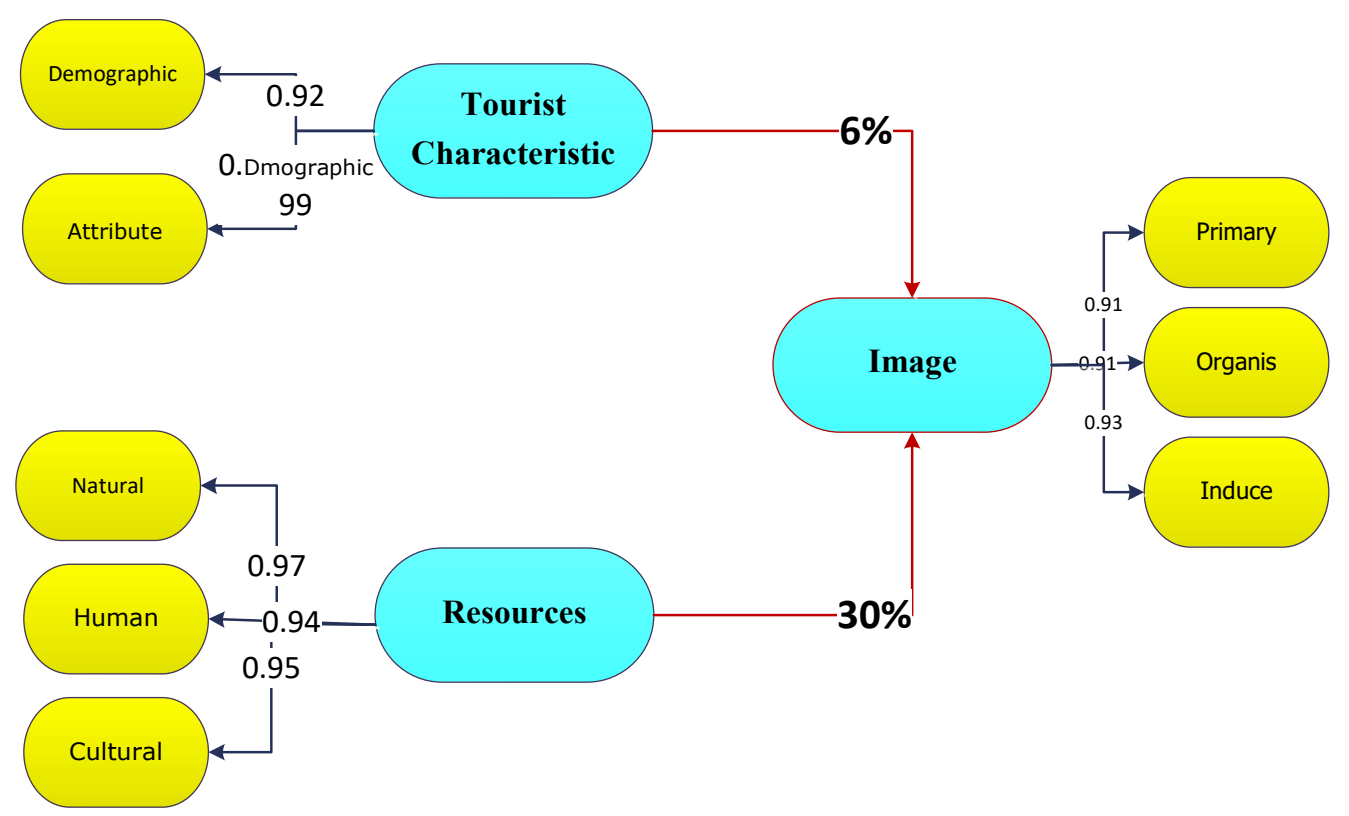

Figure 3. Research Finding

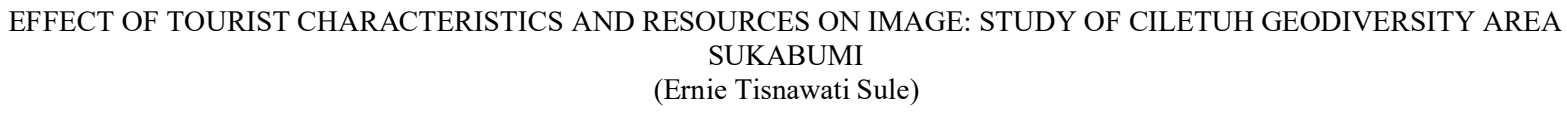


The research results show that tourist characteristics and resources affect the image. Resources show a more dominant influence of $30 \%$ than the tourist characteristics of $6 \%$. The image of Ciletuh Geopark is shaped more by the aspect of the induced image than the primary and organic images. These three types of images, hence, are more dominantly caused by resources than tourist characteristics.

The aspect of resources showing a dominant influence is natural resources, followed by cultural and human resources. Therefore, the image of Ciletuh Geopark is shaped more dominantly by the natural resources than the others. Natural resources relate to the environmental attractiveness, geological sites, and geo-site quality of the tourist destination. Cultural resources, on the other hand, relate to the variations of cultural attractions at the destination as well as their event frequency. Meanwhile, human resources are closely related to the competency and quality of the human resources managing the tourist destination.

The results of this study illustrate that the image of the Ciletuh Geopark tourist destination that is perceived by visitors is bigger because of their perception of existing resources. Tourist satisfaction in enjoying natural resources is the highest in shaping the image of the Ciletuh Geopark in the eyes of visitors. As known that Ciletuh Geopark, with an area of 128 thousand hectares, includes eight subdistricts in Sukabumi regency, has tremendous natural resources. Ciletuh Geopark offers the harmonizing of the diversity of geology, nature, culture through conservation, education, and sustainable development.

The increasingly diverse uses of social media and increasing internet penetration in the community makes it easier for tourists to find attractive destinations. Posting pictures and videos by those who have visited a tourist destination certainly creates curiosity and interest for those who see it. Captivating and attractive images encourage people to visit tourist attractions. Moreover, Ciletuh Geopark has exciting natural resources. Although there are still several problems regarding destination management, the number of visitors continues to increase. The government has anticipated this by encouraging broader cooperation with related parties. Also, the community is encouraged to take part in the development of this tourist destination. This is intended so that the attractiveness of existing natural resources and cultural resources can be utilized with the support of reliable human resources to be able to elevate the image of Ciletuh Geopark as a world-class tourist destination.

The influence of tourist characteristics on the image in this study supports the study conducted by Lopes (2011). It means the variables such as age, race, the fact that a person has visited a destination before, their level of education, 
Jurnal Bisnis dan Manajemen, Volume 21, No. 2, September 2020, p. 129-143

motivation, and cultural values strongly influence a destination's image. It shows the relationship between the tourist characteristic and the destination image. This finding also supports Jamaludin, Aziz, Yusof, \& Idris (2013), revealing the existence of causal relationships between information sources and destination image, which directly leads to positive visitor satisfaction.

The results of this research can be used as input to the management of the Ciletuh Geopark tourist area to improve the image of the destination by developing in terms of resources and by adapting the characteristics of tourists who come to the location.

\section{CONCLUSION AND RECOMMENDATIONS}

This present study investigates the effect of tourist characteristics and resources on the image of Ciletuh Geopark. The results show that those two independent variables affect the image, and the resources show a more dominant influence than the tourist characteristics.

The results of this research give a managerial implication to the management of Ciletuh Geopark, primarily regarding the importance of increasing the image of the destination. This effort can be conducted by developing and improving the management of natural resources, cultural resources, and human resources. Those efforts need also be supported by the proper understanding of the tourist characteristics because these can increase the destination's image.

\section{REFERENCES}

Abdellatif, T., Ksouri, R., Ayoun, S. Storai, C. (2014). The Importance of the Image of a Destination in the Choice and Intention of Revisiting: The Case of Island of Djerba. Available at SSRN: https://ssrn.com/abstract $=2562044$ or $\mathrm{h}$ ttp://dx.doi.org/10.2139/ssrn.2562044

Adiakurnia, M. I. (2018). Geopark Ciletuh Dapat Pengakuan UNESCO Global Geopark. Kompas Travel. https://travel.kompas.com/read/2018/04/17/17 2000427/geopark-ciletuh-dapat-pengakuanunesco-global-geopark

Aksoy, R. \& Kiyci, S. (2011). A Destination Image As a Type of Image and Measuring Destination Image in Tourism (Amasra Case). European Journal of Social Sciences. 20(3), 478-488.

Beerli, A., \& Martín, J. D. (2004). Tourists' Characteristics and The Perceived Image of Tourist Destinations: a Quantitative Analysis - a Case Study of Lanzarote, Spain. Tourism Management. 25(5): 623-636. doi: https://doi.org/10.1016/j.tourman. 2003.06.004.

Buhalis, D. (2000) Marketing the Competitive Destination of the Future. Tourism Management, 21(1), 97-116.

Cai, L. A., Wu, B., \& Bai, B. (2004). Destination image and loyalty. Tourism Review International, 7(3/4), 153-162.

Chin, W. W. (2000). Partial least squares for IS researchers: an overview and presentation of recent advances using the PLS approach. Conference: Proceedings of the twenty first international conference on Information systems.

Fakeye, P.C. \& Crompton, J.L. (1991). Differences Between Prospective, First-Time, and Repeat Visitors to the Lower Rio Grande Valley. Journal of Travel Research, 30(10).

Gaffar, V., Wetprasit, HP., P. \& Setiyorini, D. (2011). Comparative Study Of Tourist Characteristics On Cultural Heritage Tourism Sites: Survey On Tourist In Indonesia And Thailand Heritage Sites. Journal of Tourism, Hospitality \& Culinary Arts. 3(3).

Gunn, C.A. (1972). Vacationscape: Designing Tourist Regions, Taylor \& Francis, Washington.

Hosany, S., Ekinci, Y., \& Uysal, M. (2006). Destination image and destination personality: An application of branding theories to tourism 
Jurnal Bisnis dan Manajemen, Volume 21, No. 2, September 2020, p. 129-143

places. Journal of Business Research. 59. 638642. 10.1016/j.jbusres.2006.01.001.

Huete-Alcocer, N, Martinez-Ruiz, M.P, López-Ruiz V.R. \& Izquiedo-Yusta, A. (2019). Archeological Tourist Destination Image Formation: Influence of Information Sources on the Cognitive, Affective and Unique Image. Front. Psychol. 10:2382. doi: 10.3389/fpsyg.2019.02382

Itamar, H., Alam, A. S., \& Rahmatullah. (2014). Strategi Pengembangan Pariwisata di Kabupaten Tana Toraja. Government. Jurnal Ilmu Pemerintahan, 7(2), 91-108.

Jamaludin, M., Aziz, A., Yusof, A. R. M., \& Idris, N. H. (2013). Information source influence destination image. International Journal of Independent Research and Studies, 2(4), 146155.

Kim, W. H., Malek, K., Kim, N. J., \& Kim, S. H. (2017). Destination personality, destination image, and intent to recommend: The role of gender, age, cultural background, and prior experiences. Sustainability MDPI (Switzerland), $10(1)$. https://doi.org/10.3390/su10010087

Lopes, S.D.F. (2011). Destination image: Origins, Developments and Implications. Pasos. Revista de Turismo y Patrimonio Cultural. 9(2), 305-315.

Luo, M., Feng, R., \& Cai, L.A. (2004). Information Search Behavior and Tourist Characteristics. Journal of Travel \& Tourism Marketing, 17(1) :2-3, 15-25. DOI: 10.1300/J073v17n02 02

Ma, A.T.H., Chow, A.S.Y., Cheung, L.T.O., Lee, K.M.Y., \& Liu, S. (2018). Impacts of Tourists' Sociodemographic Characteristics on the Travel Motivation and Satisfaction: The Case of Protected Areas in South China. Sustainability, MDPI, Open Access Journal. 10(10) 1-21.

Madden, K., Rashid, B., Zainol, N.A. (2016). Beyond the motivation theory of destination image. Tourism and Hospitality Management, 22(2), 247-264.

Melian-Gonzalez, A \& Garcia-Falcon, J.M. (2003). Competitive potential of tourism in destinations. Annals of Tourism Research 30(1): 720-740.

Newsome, D., Moore, S.A., \& Dowling, R.K. (2012). Natural area tourism: Ecology, impacts and management. Ecotourism. Channel view publications 1280 .
Nunnally, J.C. \& Bernstein, I.H. (1994). Psychometric Theory, Edisi ke 3. New York: McGraw Hill.

Phelps, A. (1986). Holiday destination image: the problem of assessment, Tourism Management, 7(3), 168-180.

Putri, S.M., Deliarnoor, N.A. \& Nurasa, H. (2020). Implementasi Kebijakan Pemerintah Provinsi Jawa Barat Tentang Pengembangan Kawasan Geopark. Jurnal Ilmiah Ilmu Pemerintahan, 6 (1).

Soedarsono, D.K. (2018). Comparison Between Communication Systems of Tourism Objects at Unesco Global Geopark to Create Tourism Branding. Multiple Platform in Transformative Public Relations, Cultural and Tourism. ASPIKOM Indonesia. p.335-344

Triana, D., Nuraini, Q., \& Rusfien, I.T. (2020). Hubungan Kualitas Pelayanan Informasi Dengan Tingkat Kepuasan Pengunjung Di Geopark Information Center Palabuhan Ratu. Jurnal Penelitian Sosial. Vol 4. No 2. Universitas Pakuan Bogor.

Vengesayi, S., Mavondo, F., \& Reisinger, Y. (2009). Tourism destination attractiveness: Attractions, facilities, and people as predictors. Tourism Analysis, 14(5), 621 636. https://doi.org/10.3727/108354209X1259 7959359211.

World Tourism Organization. (2003). WTO Think Tank Enthusiastically Reaches Consensus on Frameworks for Tourism Destination Success. Retrieved 11 March,2003a

Yusuf, I.D.S., Rostitawati, T. \& Obie, M. (2019). Cultural And Natural Resources As A Tourism Destination In Gorontalo Regency - Indonesia: Its Potentials, Problems, And Development. International Journal of Tourism \& Hospitality Reviews. eISSN: 2395-7654. 6(2), 01-07. https://doi.org/10.18510/ijthr.2019.621 